\title{
Актуальні проблеми невідкладної хірургії колоректального раку
}

\author{
B. O. MATVIYCHUK, O. B. MATVIYCHUK, M. T. FETSYCH
}

Lviv National Medical University by Danylo Halytskyi

\section{ACTUAL PROBLEMS OF EMERGENCY SURGERY OF COLORECTAL CANCER}

\begin{abstract}
Здійснено ретроспективний аналіз результатів лікування 136 хворих на ускладнений рак товстої кишки, оперованих у клініці в 2008-2014 рр. Вік пацієнтів перебував у межах 36-94 років (середній - (68,8 $\pm 12,1$ року). У більшості хворих РТК діагностовано в клініці у зв'язку з виникненням того чи іншого ускладнення - 117 (86 \%). Домінуючим ускладненням колоректального раку виявилась гостра обтураційна непрохідність - ізольовано у 105 (77,2 \%) хворих, у поєднанні 3 перфорацією пухлини, перитонітом - у 24 (17,6 \%) пацієнтів, кишковою кровотечею - в 1 (0,8 \%) хворого. Перфорацію пухлини, перитоніт констатовано у 3 (2,2 \%) хворих, гостру кишкову кровотечу - в 3 (2,2 \%) пацієнтів. У 81,1 \% спостережень перитоніт мав дифузний характер. Радикальні операції виконано у 68 (50 \%) хворих, паліативні-у 18 (13,2 \%), симптоматичні - в 50 (36,8 \%) пацієнтів. Відповідно до класифікації TNM, I стадію пухлини встановлено у 0,7 \% оперованих, II стадію - у 31 \% хворих, III і IV стадії, відповідно, - у 31,4 та 37,0 \% пацієнтів. Післяопераційні ускладнення розвинулись у 10 хворих $(7,3$ \%) і мали в основному гнійно-септичний характер. Появу третинного перитоніту було визнано у 17 (12,5 \%) прооперованих. Релапаротомії виконано 21 хворому (15,4 \%), здебільшого з причини перитоніту, ретракції колостом. Середній ліжко-день склав 16,2+7,7. Померли 23 хворі - післяопераційна летальність - 16,9 \%. Третинний перитоніт призвів до летального кінця в 15 пацієнтів (88,2 \%). Основною причиною смерті визнано поліорганну недостатність як прояв тяжкого сепсису. Основними аспектами проблеми ускладненого раку товстої кишки (УРТК), які потребують комплексного вирішення, є зростання захворюваності, запізніла госпіталізація пацієнтів, потенційований ризик венозних тромбозів та емболій, третинний перитоніт, підвищення фахової онкологічної підготовки хірургів.
\end{abstract}

The article gives the retrospective analysis of treatment of 136 patients with complicated colon cancer, who underwent surgery in 2008-2014. The age of patients was within 36-94 years (average - $(68.8 \pm 12.1)$ ). In majority of patients, colorectal cancer was diagnosed in the hospital due to the development of complication - $117(86 \%)$. The dominant complication of colorectal cancer was the acute obstructive ileus - isolated, in 105 (77.2 \%) patients; in combination with tumor perforation, peritonitis - in 24 (17.6 \%); with intestinal bleeding - in $1(0.8 \%)$ case. Perforation of the tumor, peritonitis was stated in $3(2.2 \%)$ patients, acute intestinal bleeding - in $3(2.2 \%)$. In $81.1 \%$ of cases, peritonitis had diffuse character. Radical surgery was performed in 68 (50 \%) patients, palliative - in 18 (13.2 \%), symptomatic - in 50 (36.8\%) patients. In accordance with the TNM classification, Ist stage was diagnosed in $0.7 \%$ of the operated, IInd - in $31 \%$, IIIrd and IVth - in $31.4 \%$ and $37.0 \%$ of patients respectively. Postoperative complications developed in 10 patients (7.3\%) and had mainly septic character. Tertiary peritonitis was found in $17(12.5 \%)$ of the operated. Relaparotomies were made in 21 patients (15.4\%), mainly due to peritonitis, colostoma retraction. Average hospital stay was 16.2 \pm 7.7 . Twenty-three patients died, postoperative mortality - $16.9 \%$. Tertiary peritonitis resulted in death of 15 patients (88.2 \%). The main cause of death was multiple organ failure as a manifestation of severe sepsis. The main aspects of the problem of complicated colon cancer, which require complex solution, are increased morbidity, delayed hospitalization, potentiated risk of venous thrombosis and embolism, tertiary peritonitis, improvement of professional oncological training of surgeons.

Постановка проблеми і аналіз останніх досліджень та публікацій. Всупереч безсумнівним досягненням світової клінічної онкології, до $20 \%$ випадків раку товстої кишки (РТК) діагностують у зв’язку з розвитком ускладнень: гострої обтураційної непрохідності, перфорації, кровотечі [1, 3, 5]. За статистичними даними Національного канцер-реєстру України, починаючи з 2010 р., захворюваність на РТК займає перше місце у нозологічній структурі злоякісних пухлин [3, 4].

Як правило, хворих на ускладнений колоректальний рак госпіталізують в ургентному порядку в загальнохірургічні стаціонари усіх рівнів - від районної лікарні до університетської клініки [2]. В силу існуючих настанов у виборі тактики лікування домінує підхід, спрямований лише на усунення ускладнень, які загрожують життю: гострої непрохідності кишки, перитоніту, кровотечі [3, 5]. Вирішення онкологічного аспекту проблеми радикальної операції - відкладають на невизначений час, що істотно погіршує виживання хворих $[4,7,8,9]$.

Курація хворих, оперованих з приводу ускладненого раку товстої кишки (УРТК), вирізняється особливою складністю. Отож, протокольна фармакопрофілактика венозних тромбозів та емболій, ризик 
яких є високим у пацієнтів із УРТК, стає проблематичною при виконанні невідкладних операційних втручань. Заавансований вік хворих, фонова імуносупресія та пролонговане перебування оперованих у відділеннях анестезіології та інтенсивної терапії (BАIT) створюють реальну загрозу для виникнення одного з найбільш небезпечних для життя пацієнтів різновиду госпітальної інфекції - третинного перитоніту.

Тяжкі ускладнення та висока післяопераційна летальність залишають УРТК актуальною і невирішеною проблемою невідкладної абдомінальної хірургї̈ та онкології.

Мета роботи: визначити найбільш актуальні проблеми невідкладної хірургії ускладненого колоректального раку та шляхи їх вирішення.

Матеріали і методи. Дослідженням охоплено 136 хворих на УРТК, оперованих у клініці хірургії та ендоскопії (клінічна база - 1 та 3 хірургічні відділення Комунальної клінічної лікарні швидкої медичної допомоги міста Львова) упродовж 2008-2014 pр. Незначно переважали жінки - 78 (57,3 \%). Вік пацієнтів перебував в межах 36-94 роки (середній - $(68,8 \pm 12,1)$ року). Тривалість догоспітального періоду була в межах 1-11 діб (в середньому - $(5,3 \pm 4,9)$ року). Основну частину пацієнтів поміщено в клініку за скеруванням швидкої медичної допомоги - 130 (95,5%). У більшості хворих РТК діагностовано в клініці у зв'язку з виникненням того чи іншого ускладнення - 117 (86 \%). У 7 пацієнтів (5 \%) діагноз колоректального раку був встановлений раніше, однак за відсутності їх згоди вони не були оперовані. Дванадцять пацієнтів (9\%) відзначили в анамнезі злоякісні пухлини інших локалізацій.

Діагностика УРТК полягала в аналізі скарг та даних об’єктивного обстеження, застосуванні лабораторних, променевих (оглядова рентгеноскопія живота, УЗД, комп’ютерна томографія) та інструментальних (колоноскопія) методів. Домінуючим ускладненням колоректального раку виявилась гостра обтураційна непрохідність - ізольовано у 105 (77,2 \%) хворих, у поєднанні з перфорацією пухлини, перитонітом - у 24 (17,6 \%), кишковою кровотечею в 1 (0,8 \%) випадку. Перфорацію пухлини, перитоніт констатовано у 3 (2,2 \%) хворих, гостру кишкову кровотечу - в 3 (2,2 \%) пацієнтів. У 81,1 \% спостережень перитоніт мав дифузний характер.

3 метою підтримки вітальних функцій організму всім хворим проводили передопераційне приготування шляхом відновлення водно-електролітної та білкової рівноваги, знеболювання, корекції декомпенсації супровідних захворювань. Антибіотикопрофілактику відповідно до прийнятих стандартів перед операцією застосовано у 97,3 \% хворих, фармакопрофілактику венозних тромбозів та емболій переважно низькомолекулярними гепаринами - у 84,7 \% пацієнтів. Способом вибору знеболювання був ендотрахеальний наркоз. Лише у 5 (3,7 \%) випадках цекостомію виконано під місцевою інфільтраційною анестезією у зв’язку з вкрай високим анестезіологічним ризиком.

Радикальні операції у 68 (50%) хворих передбачали резекцію кишки з пухлиною та видалення чотирьох колекторів регіональних лімфовузлів в онкологічно визначених межах, формування первинного анастомозу або термінальної колостомії. Паліативні резекції у 18 хворих (13,2 \%) полягали у видаленні сегмента товстої кишки $з$ пухлиною, колостомії і вимушеному залишенні пухлинного субстрату в черевній порожнині. У 50 (36,8 \%) пацієнтів виконано симптоматичні операції. Занедбаний рак та високий операційний ризик, насамперед у пацієнтів iз віддаленими метастазами, були основними чинниками, які зумовили обмеження обсягу операцій до накладання декомпресійної стоми або формування обвідних анастомозів.

Відповідно до класифікації TNM (6 видання, 2002 р.), для визначення характеру і стадіювання пухлинного процесу враховували інтраопераційні дані щодо поширення РТК та результати патоморфологічних досліджень операційних препаратів. Отож, I стадію пухлини встановлено у 0,7 \% оперованих, II стадію - у 31 \% хворих, III і IV стадії, відповідно, - у 31,4 та 37,0 \% пацієнтів. Згідно 3 патоморфологічними висновками операційних препаратів переважали аденокарциноми різного ступеня диференціації (G1-3) (88,9%), рідше зустрічався муцинозний (7,9 \%) або недиференційований рак (3,3 \%).

В усіх випадках перитоніту здійснювали забір ексудату для мікробіологічного дослідження. Значну більшість пацієнтів - 128 (94,1 \%) після закінчення операції було поміщено у ВАІТ для інтенсивного спостереження та лікування, де перебували від 1,3 до 18,4 доби (в середньому - 2,8土1,3). Післяопераційні ускладнення розвинулись у 10 хворих (7,3 \%) і мали в основному гнійно-септичний характер. Появу третинного перитоніту було визнано у 17 (12,5 \%) прооперованих. Критеріями встановлення цього діагнозу було перебування у BAIT 3 і більше діб, відсутність регресії перитонеальних явищ, неефективність протимікробної, зокрема раціональної антибіотикотерапії, наявність ознак поліорганної недостатності та опортуністичної мікрофлори (Citrobacter Freundii, Acinetobacter Baumannii, Staphylococcus viridans, Pseudomonas spp., Candida spp., Geotrichum candidum), висіяної з черевної порожнини.

Релапаротомії виконано 21 хворому (15,4 \%) здебільшого з причини перитоніту, ретракції колостом.

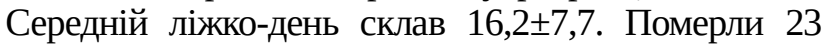
хворі - післяопераційна летальність - 16,9 \%. Тре- 
тинний перитоніт призвів до летального кінця в 15 пацієнтів (88,2 \%). Основною причиною смерті визнано поліорганну недостатність як прояв тяжкого сепсису.

Результати досліджень та їх обговорення. Проведене дослідження дало можливість виокремити низку аспектів проблеми невідкладної хірургії колоректального раку, вирішення яких спроможне покращити результати лікування цього, одного з найтяжчих контингентів хворих.

Зростання захворюваності на УРТК.

Упродовж періоду дослідження відзначено зростання числа хворих на УРТК (табл.1).

Таблиця 1. Кількість хворих на УРТК у розрізі років

\begin{tabular}{|c|c|c|c|c|c|c|c||}
\hline \hline \multirow{2}{*}{ УКРР } & \multicolumn{9}{|c|}{ Роки } & 2013 & 2014 \\
\cline { 2 - 9 } & 2008 & 2009 & 2010 & 2011 & 2012 & 21 & 20 \\
\hline $\mathrm{n}$ & 13 & 18 & 16 & 24 & 24 & 213 & 24 \\
\hline
\end{tabular}

Деяке зменшення кількості хворих у 2013-2014 pp. найімовірніше зумовлено міграційними процесами. Зниження рівня захворюваності на колоректальний рак i, відповідно, УРТК можливе за умови ефективного проведення скринінгу передракових станів.

Запізніла госпіталізація пацієнтів із УРТК.

Тривалий час до звертання за медичною допомогою і запізніла госпіталізація (більше 1 доби) різко знижують можливості виконання радикальних операцій, підвищують ймовірність перфорації пухлини з розвитком калового перитоніту, що значно збільшує ризик операції та летального їі результату. Необхідно послідовно підвищувати онкологічну настороженість населення, пояснювати небезпеку самолікування при виникненні навіть часткової затримки калу й газів. У цьому зв'язку доцільно було б заборонити рекламу на телебаченні різноманітних проносних лікарських засобів.

Поява УРТК не означає неможливості куративного лікування.

Саме сприятлива кінетика раку товстої кишки зумовлює реальність виконання онкологічно радикального хірургічного втручання [5, 7]. Поділ проблеми лікування пацієнта із УРТК на суто хірургічний (ліквідація ускладнення) та онкологічний (радикальне видалення пухлини) є хибним, що не сприяє виживанню пацієнтів. У складі кожного відділення, що надає невідкладну хірургічну допомогу, повинен бути фахівець, який володіє навичками виконання радикальних операцій при раку товстої кишки.

УРТК становить потенційований ризик венозних тромбозів та емболій.

\section{СПИСОК ЛІТЕРАТУРИ}

1. Березницький Я. С. Уніфікація формування клінічного діагнозу та надання медичної допомоги в невідкладній колопроктології / Я. С. Березницький, В. В. Гапонов, В. П. Сулима // Харківська хірургічна школа. - 2009. - № 2. - С. 9-11. 2. Иоффе И. В. Особенности клинического течения и хирургической тактики при острой толстокишечной непроходимости / И. В. Иоффе, Ю. А. Хунов, Н. А. Шор // Український журнал хірургії. - № 5. - 2009. - С. 97-100.
Високий ризик венозних тромбозів та емболій $€$ безсумнівним [6]. Поява УРТК, зокрема гострої непрохідності та перитоніту, в силу зневоднення хворого і наростаючої ендогенної інтоксикації різко збільшує ймовірність тромботичних ускладнень. Фармакопрофілактика максимально можливими дозами прямих антикоагулянтів повинна бути ініційована перед операцією і продовжена після неї до 28 дня.

Третинний перитоніт - у більшості фатальне ускладнення у хворих на УРТК.

Госпітальна інфекція в хворого із ускладненнями колоректального раку на тлі імуносупресї-летальний тандем невідкладної хірургї УРТК [5]. Якнайшвидша раціоналізація антибіотикотерапії, мінімізація перебування хворих у ВАІТ, динамічний мікробіологічний контроль, комплексне лікування перитоніту, виважена імунотерапія є реальними шляхами профілактики та лікування третинного перитоніту.

Висновки. 1. Гостра обтураційна непрохідність найчастіше ускладнення колоректального раку.

2. Кожному другому хворому з УРТК, незважаючи на ускладнення, реально виконати куративне хірургічне втручання.

3. Третинний перитоніт - одне 3 найтяжчих ускладнень післяопераційного періоду.

Перспективи подалыших досліджень. Перспектива подальших досліджень проблеми УРТК полягає в консолідації наукового потенціалу та практичних зусиль хірургів, онкологів, клінічних мікробіологів та імунологів.

3. Ковальчук Л. Я. Хірургічна тактика при діастатичних розривах товстої кишки на фоні обтураційної кишкової непрохідності / Л. Я. Ковальчук, А. Д. Беденюк, Т. Ю. Угляр // Шпитальна хірургія. - 2011. - № 3. - С. 41-45.

4. Тамм Т. И. Результаты лечения больных колоректальным раком, осложнённым кишечной непроходимостью / Т. И. Тамм, Ю. А. Гвоздик, А. Я. Бардюк // Хірургічна перспектива. 2011. - № 1. - С. 85-89. 


\section{З ДОСВІДУ РОБОТИ}

5. Фомін П. Д. Результат оперативного лікування обтураційної товстокишкової непрохідності ракової природи / П. Д. Фомін, О. В. Заплавський, О. Б. Бєляков-Бельський // Науковий вісник Ужгородського університету. - Ужгород, 2001. - Вип. 14. - С. 49-51. - (Серія “Медицина").

6. Agnelli G. A clinical outcome-based prospective study in venous thromboembolism after cancer surgery: the ARISTOS project / G. Agnelli, G. Bolis, L. Capusotti // Ann. Surg. 2006. Vol. 243. - P. 89-95.

7. Health disparity in complicated colorectal cancer / K. C. Bow- man, P. Tabrizian, D. A. Telem [et al.] // Am.Surg. - 2010. - Vol. 76, № 2. - P. 164-167.

8. Leong Q. M. Emergency Hartmann's procedure: morbidity, mortality and reversal rates among / Q. M. Leong, D. C. Koh, C. K. Ho // Asians Tech. Coloproctol. - 2008. - Vol.12, № 1. P. 21-25.

9. Meyer F. Hartmann's procedure for perforated diverticulitis and malignant left-sided colorectal obstruction and perforation / F. Meyer, R. T. Grundmann // Zentralbl. Chir. - 2011. - Vol. 1361. - P. 25-33.

Отримано 05.03.15 